\title{
Anti-MOG encephalitis mimicking small vessel CNS vasculitis
}

Kristina Patterson, MD, PhD, Estibaliz Iglesias, MD, PhD, Maclean Nasrallah, MD, PhD, Verónica GonzálezÁlvarez, MD, Mariona Suñol, MD, Jordi Anton, MD, PhD, Albert Saiz, MD, PhD, Eric Lancaster, MD, PhD, and Thaís Armangue, MD, PhD

Neurol Neuroimmunol Neuroinflamm 2019;6:e538. doi:10.1212/NXI.0000000000000538

\section{Abstract}

\section{Objective}

To report 2 patients with anti-myelin oligodendrocyte glycoprotein (MOG)-associated encephalitis who were initially misdiagnosed with small vessel primary CNS vasculitis.

\section{Methods}

Review of symptoms, MRI and neuropathologic features, and response to treatment. MOG antibodies were determined in serum and CSF using a cell-based assay.

\section{Results}

Symptoms included fever, headache, and progressive mental status changes and focal neurologic deficits. CSF studies revealed lymphocytic pleocytosis, and both patients had abnormal brain MRIs. Brain biopsy samples showed prominent lymphocytic infiltration of the wall of small vessels; these findings initially suggested small vessel CNS vasculitis, and both patients were treated accordingly. Although 1 patient had a relapsing-remitting course not responsive to cyclophosphamide, the other one (also treated with cyclophosphamide) did not relapse. Retrospective assessment of serum and CSF demonstrated MOG antibodies in both cases, and review of biopsy specimens showed absence of fibrinoid necrosis (a pathologic requirement for small vessel CNS vasculitis).

\section{Conclusions}

Anti-MOG-associated encephalitis can be mistaken for small vessel CNS vasculitis. This is important because the diagnosis of anti-MOG-associated encephalitis does not require brain biopsy and can be established with a serologic test.

\author{
Correspondence \\ Dr. Armangue \\ armangue@clinic.cat
}

\section{RELATED ARTICLE}

\section{Editorial}

Diagnostic challenges and

pitfalls of myelin

oligodendrocyte

glycoprotein

antibody-associated

demyelination: Lessons

from neuropathology

Page e544

From the Neurology Department (K.P., E.L.), University of Pennsylvania, Philadelphia; Rheumatology Department, Sant Joan de Deu Children's Hospital (E.I., J.A.), University of Barcelona, Spain; Department of Pathology (M.N.), University of Pennsylvania, Philadelphia; Pediatric Neuroimmunology Unit (V.G.-Á., T.A.), Sant Joan de Déu Children's Hospital, University of Barcelona, Spain; Department of Pathology (M.S.), Sant Joan de Déu Children's Hospital, University of Barcelona, Spain; and Neuroimmunology Program (A.S., T.A.), IDIBAPS-Hospital Clinic, University of Barcelona, Spain.

Funding information and disclosures are provided at the end of the article. Full disclosure form information provided by the authors is available with the full text of this article at Neurology.org/NN.

The Article Processing Charge was funded by the Clinic Foundation.

This is an open access article distributed under the terms of the Creative Commons Attribution-NonCommercial-NoDerivatives License 4.0 (CC BY-NC-ND), which permits downloading and sharing the work provided it is properly cited. The work cannot be changed in any way or used commercially without permission from the journal. 


\section{Glossary}

MMF = mycophenolate mofetil; MOG = myelin oligodendrocyte glycoprotein.

The diagnosis of small vessel primary CNS vasculitis is challenging because conventional and brain MRI angiography are negative, and brain biopsy remains as the only definite diagnostic test. ${ }^{1}$ However, brain biopsy is invasive and may be uninformative because of sampling error. Here, we describe 2 patients with myelin oligodendrocyte glycoprotein (MOG) antibody-associated encephalitis ${ }^{2}$ who were initially misdiagnosed with small vessel CNS vasculitis based on biopsy findings. Physicians should be aware of this potential misdiagnosis because it has important clinical implications.

\section{Case 1}

A 5-year-old boy presented with 2 weeks of frontal headache and fever. His physical examination showed decreased alertness and bilateral papilledema (table). Brain CT and MRI (figure 1A) were normal, and the CSF showed pleocytosis. Meningoencephalitis was suspected, and he was started on steroids and acyclovir. During the following days, he developed visual hallucinations. There was gradual clinical improvement until complete recovery, and the patient was discharged on steroid taper 1 month later. In the ensuing 4 months, he was readmitted 3 times for relapsing symptoms while weaning from steroids. Repeat brain MRI showed T2 abnormalities in the basal ganglia, cerebellar peduncles, and supratentorial white matter (figure 1B-D), and CSF pleocytosis was identified in all episodes (table). All relapses substantially improved after treatment with steroids. At the last relapse, a conventional brain angiography was inconclusive. Brain biopsy showed infiltrates of lymphocytes involving the wall of small vessels and perivascular areas accompanied by perivascular demyelination (figure 2A-D). The patient was diagnosed with primary CNS vasculitis, and he was started on monthly pulses of cyclophosphamide. After the 5th pulse, he developed acute right optic neuritis that was treated with steroids, resulting in little improvement. Extensive blood testing identified an elevation of lipoprotein A (also present in his asymptomatic father), and oral aspirin was added, together with mycophenolate mofetil (MMF) and prednisone. He remained clinically and radiologically stable (figure $1 \mathrm{E}$ ), with a right eye visual deficit for 2 years; at this time, immunosuppression was weaned, and shortly after stopping the steroids (while on MMF and aspirin), he developed confusion and decreased level of consciousness. MRI showed extensive white matter abnormalities (figure $1 \mathrm{~F}$ ) and high serum titer of MOG antibodies (1:640). Retrospective assessment of stored serum and CSF obtained at onset of the disease were also positive for MOG antibodies (serum titer 1:20,480 and CSF 1:320, table). Review of the paraffin block containing the brain biopsy showed that the inflammatory infiltrates were not confined to the vessel wall and also involved the white and gray matter. With these findings, the patient was diagnosed with anti-MOG encephalitis, and treatment with rituximab, azathioprine, and low-dose prednisone was initiated. No more relapses were observed; at the last follow-up, 3 years later, he remained clinically and radiologically stable on azathioprine and low-dose prednisone (eventually discontinued), and the serum titer of MOG immunoglobulin G (IgG) antibodies had decreased (1:80) below the consensus limit of positivity $(\geq 1: 160))^{2,3}$

\section{Case 2}

A 39-year-old woman with a history of ulcerative colitis treated with mesalamine and budesonide developed severe, progressive left temporo-parietal headache associated with nausea and photophobia. Shortly after neurologic symptom onset, she developed intermittent fever. Peripheral leukocytosis with neutrophilic predominance and elevated C-reactive protein were identified (table). Brain MRI showed hyperintense gyriform fluid-attenuated inversion recovery signal over the left temporal, parietal, and occipital lobes (figure 1G-H). CSF analysis showed pleocytosis and elevated protein concentration, and the patient was started on empiric antibiotics and acyclovir. Six days later, she developed expressive aphasia, confusion, and agitation, and bilateral VI cranial nerve palsies. Repeat brain MRI showed no changes, and CT angiography demonstrated no clear evidence of vasculitis. A biopsy of the left parietal lobe and dura showed interstitial and perivascular lymphocytic infiltrates with marked involvement of the vessel wall (figure $2 \mathrm{E}-\mathrm{H})$. There was no clear evidence of demyelination (data not shown). These findings led to suspect CNS vasculitis, and high-dose IV steroids and oral cyclophosphamide were started. Four months later, cyclophosphamide was discontinued because of elevated transaminases. The dose of prednisone was tapered over the course of 2 years. During the follow-up, the brain MRI normalized at 4 months and the neurologic examination at 9 months; her only complaints were mild aphasia when tired and chronic daily headache. Retrospective analysis of stored CSF obtained by the time of symptom onset showed MOG-IgG antibodies (1:8).

\section{Discussion}

We describe 2 patients initially diagnosed with small vessel CNS vasculitis but who in fact had anti-MOG-associated encephalitis. The first patient received standard treatment for CNS vasculitis, including cyclophosphamide and steroidsparing drugs. Although this treatment led to initial stabilization of symptoms, the patient developed new relapses until 


\begin{tabular}{|c|c|c|c|c|c|c|c|}
\hline & Patient 1 & & & & & & Patient 2 \\
\hline Age, sex & 5 years, male & & & & & & 39 years, female \\
\hline Previous history & None & & & & & & Ulcerative colitis \\
\hline Attack & 1 & 2 & 3 & 4 & 5 & 6 & 1 \\
\hline Time from disease onset & Onset & $+4 \mathrm{wk}$ & $+6 \mathrm{wk}$ & $+4 \mathrm{mo}$ & $+8 \mathrm{mo}$ & +30 mo & Onset \\
\hline Symptoms & $\begin{array}{l}\text { Headache, LGF, } \\
\text { papilledema, bilateral } \\
\text { visual loss, confusion, } \\
\text { and hallucinations }\end{array}$ & Headache and LGF & $\begin{array}{l}\text { Headache, blurry } \\
\text { vision, unsteady gait, } \\
\text { and DLC }\end{array}$ & $\begin{array}{l}\text { LGF, right leg paresis, } \\
\text { hallucinations, and DLC }\end{array}$ & $\begin{array}{l}\text { Pain, severe loss of } \\
\text { vision on the right eye, } \\
\text { and papilledema }\end{array}$ & Confusion and DLC & $\begin{array}{l}\text { Headache, nausea, } \\
\text { photophobia, fatigue, } \\
\text { diarrhea, LGF, } \\
\text { aphasia, and } \\
\text { irritability. Later: } \\
\text { bilateral VI cranial } \\
\text { nerve palsy }\end{array}$ \\
\hline $\begin{array}{l}\text { Systemic inflammatory } \\
\text { markers }\end{array}$ & Normal CRP and ESR & $\begin{array}{l}\text { Normal CRP, ESR, and } \\
\text { ferritin }\end{array}$ & Normal CRP and ESR & $\begin{array}{l}\text { Normal CRP, ESR, } \\
\text { elevation of lipoprotein A, } \\
\text { and elevated vWF }(150 \%)^{\mathrm{b}}\end{array}$ & n.d. & Normal CRP, ESR, and vWF & $\begin{array}{l}\text { Mildly elevated CRP } \\
(3.62 \mathrm{mg} / \mathrm{dL}) \text { and } \\
\text { normal ferritin }\end{array}$ \\
\hline CSF studies & $1 \mathrm{st} d ; 4$ th d & & & & & & 1 st d; 7th d; 8th d \\
\hline WBC (cell/mm m $\left.^{3}\right)$ & $50 ; 5$ & 40 & 10 & 30 & n.d. & 5 & $64 ; 146 ; 112$ \\
\hline Protein $(\mathrm{mg} / \mathrm{dL})$ & $31 ; 26$ & 54 & 50 & 68 & n.d. & 29 & $49 ; 65 ; 98$ \\
\hline $\begin{array}{l}\text { Neopterin (nmol/L) } \\
\text { (NR 9-55) }\end{array}$ & 115 & 528 & n.d. & 146 & n.d. & 36 & \\
\hline OCB & & & Positive & Negative & & & \\
\hline $\begin{array}{l}\text { Anti-MOG Ab serum } \\
\text { titer; CSF titer }\end{array}$ & n.d.; positive (1: 320) & Positive (1:20480); n.d. & n.d.; n.d. & n.d.; n.d. & Positive (1:2,560); n.d. & Positive (1:640); n.d. & n.d.; positive $(1: 8)$ \\
\hline Brain MRI & Normal (figure 1A) & $\begin{array}{l}\text { Basal ganglia (figure } \\
\text { 1B) }\end{array}$ & $\begin{array}{l}\text { Cerebral peduncle } \\
\text { (figure 1C) }\end{array}$ & $\begin{array}{l}\text { Asymmetric large hazy } \\
\text { white matter and basal } \\
\text { ganglia lesions (figure 1D) }\end{array}$ & $\begin{array}{l}\text { No new lesions; } \\
\text { residual extensive } \\
\text { white matter lesions } \\
\text { (figure } 1 \mathrm{E} \text { ) }\end{array}$ & $\begin{array}{l}\text { New large hazy white } \\
\text { matter lesions (figure 1F) }\end{array}$ & $\begin{array}{l}\text { T2/FLAIR cortical } \\
\text { hypersignal, edema, } \\
\text { meningeal } \\
\text { enhancement. Solitary } \\
\text { enhancing T2 } \\
\text { hyperintense white } \\
\text { matter lesions (figure } \\
\text { 1, G-H) }\end{array}$ \\
\hline Treatment & $\begin{array}{l}\text { Acyclovir, IV } \\
\text { dexamethasone, oral } \\
\text { steroids, and } \\
\text { levomepromazine }\end{array}$ & $\begin{array}{l}\text { Acyclovir, IV } \\
\text { methylprednisolone, } \\
\text { and oral steroids }\end{array}$ & $\begin{array}{l}\text { IVlg, oral steroids, and } \\
\text { nifedipine }\end{array}$ & $\begin{array}{l}\text { IV methylprednisolone, } \\
\text { oral steroids, and pulses } \\
\text { of CYC }\end{array}$ & $\begin{array}{l}\text { IV } \\
\text { methylprednisolone, } \\
\text { oral steroids, MM, and } \\
\text { aspirin }\end{array}$ & $\begin{array}{l}\text { IV methylprednisolone, } \\
\text { AZA, RTX, oral steroids, } \\
\text { and aspirin }\end{array}$ & $\begin{array}{l}\text { Vancomycin, } \\
\text { ceftriaxone, } \\
\text { doxycycline acyclovir, } \\
\text { and IVIg. After brain } \\
\text { biopsy: IV steroids, } \\
\text { CYC, MM, and oral } \\
\text { steroids }\end{array}$ \\
\hline
\end{tabular}




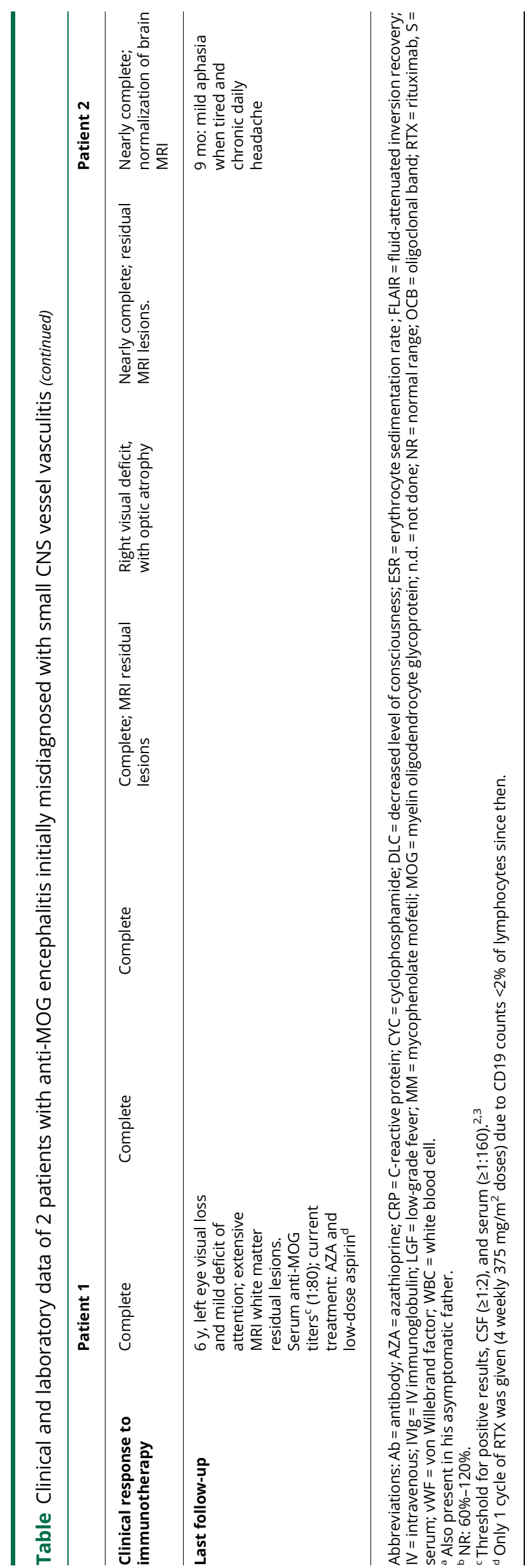

he was transitioned to a B-cell depletion therapy with good clinical and serologic response. In the second patient, the finding of MOG antibodies did not change the treatment strategy because she was already clinically stable; however, an earlier detection of these antibodies could have prevented the brain biopsy.

In retrospect, none of these patients fulfilled the criteria for small vessel CNS vasculitis. Although the presence of inflammatory cells in the vessel walls is sufficient to diagnose medium or large vessel vasculitis, signs of vessel damage such as fibrin deposition and/or necrosis (absent in our patients) must also be present to meet the criteria for small vessel vasculitis. Diapedesis of leukocytes takes place in small vessels, and the presence of inflammatory cells in the walls does not necessarily imply a pathologic process. Moreover, the pathology of CNS vasculitis is usually focal or segmental, and the brain biopsy specimen can be negative or not meet the full diagnostic criteria. ${ }^{4}$ As our patients reveal, the presence of lymphoid cells in vessel walls must be interpreted with caution, particularly when the differential diagnosis includes encephalitis with lymphocytic infiltrates. In this context, the presence of lymphocytes in the brain parenchyma away from the vessel walls favors secondary involvement of the vessels rather than a primary vasculitic process. Whether other cases of anti-MOG encephalitis may have been misdiagnosed as $\mathrm{CNS}$ vasculitis is unknown. There are reports of patients diagnosed with CNS small vessel vasculitis by brain biopsy who later developed myelitis or optic neuritis ${ }^{5}$ (symptoms suggestive of MOG encephalitis), ${ }^{2,3}$ making us to postulate that this misdiagnosis may not be unusual.

\section{Acknowledgment}

The authors thank Professor Josep Dalmau for his valuable critical review of the manuscript.

\section{Study funding}

This study was supported in part by Fundació Marató de TV3 (20141830).

\section{Disclosure}

K. Patterson received research support from the NIH/NINDS. E. Iglesias, M. Narallah, V. Gonzalez-Alverez, and M. Sunol report no disclosures. J. Anton served on the scientific advisory boards of Novartis, Sobi, and Gebro; received travel funding and/or speaker honoraria from AbbVie, Roche, Pfizer, Sobi, and Gebro; and served on the speakers' bureau of AbbVie, Pfizer, Roche, and Gebro. A. Saiz received consulting compensation and speaker honoraria from BayerSchering, Merck Serono, Biogen Idec, Sanofi-Aventis, Teva, Novartis, and Roche. E. Lancaster served on the advisory boards of Grifols, Amgen, and Janssen; received speaker honoraria and travel funding from Grifols; consulted for Medimmune, Merck, and Novartis; received fees from the Federal Vaccine Injury Compensation Program; received research support from Grifols and the NINDS; and provided 

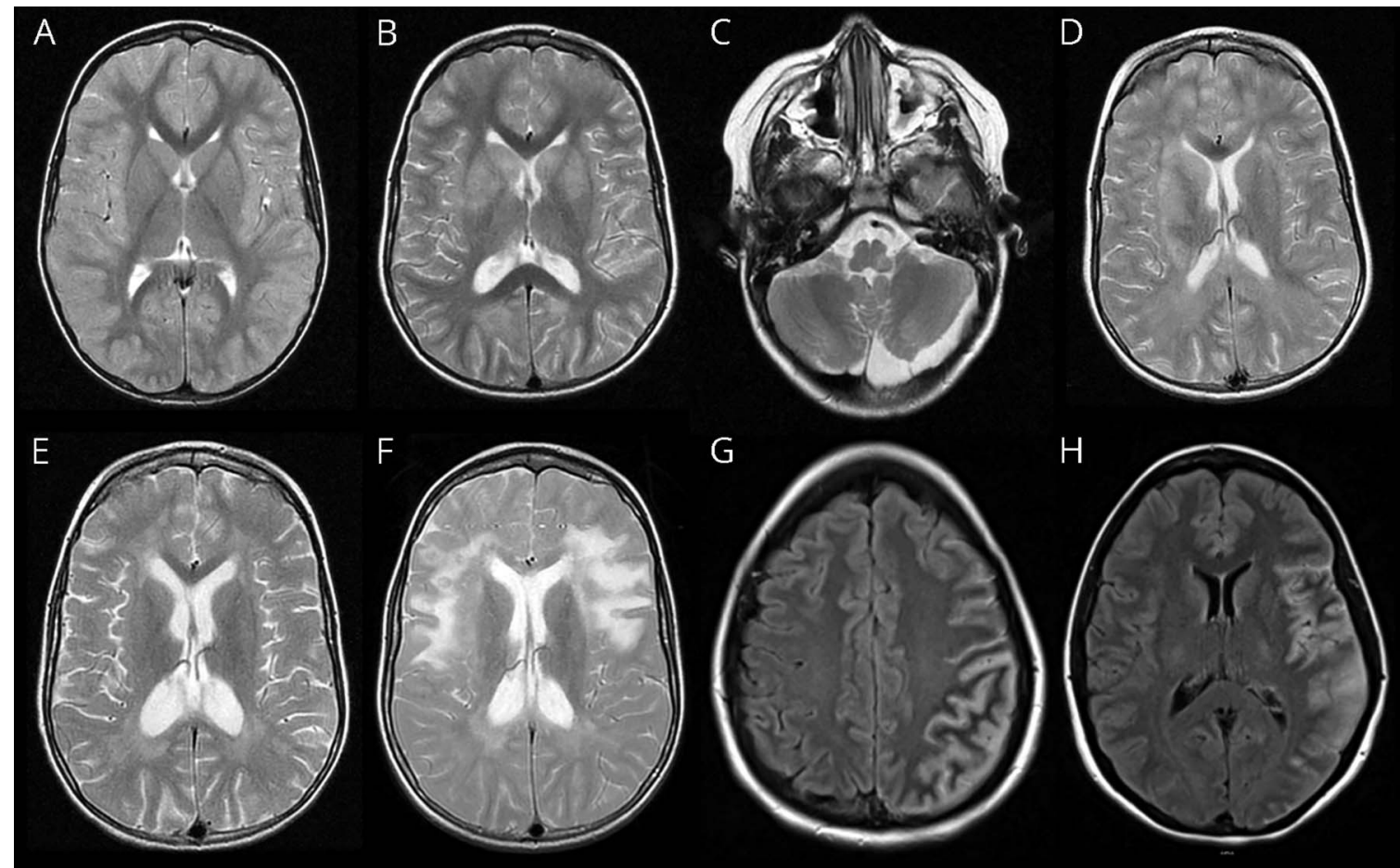

G
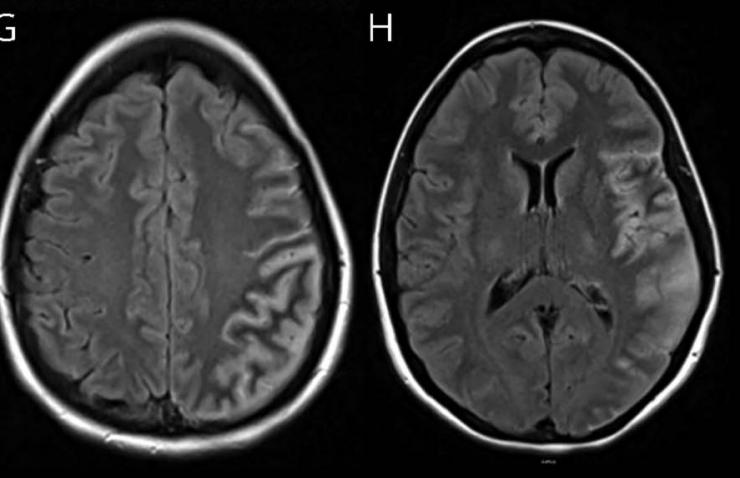

Patient 1: (A) Axial T2 MRI sequence showing no abnormalities at disease onset; (B) bilateral involvement of the basal ganglia 4 weeks after disease onset while steroids were being decreased; (C) left cerebral peduncle abnormality at 6-week follow-up; (D) asymmetric large hazy white matter and basal ganglia lesions at 4 months; (E) residual white matter lesions and enlargement of ventricles due to brain atrophy; and $(\mathrm{F})$ new asymmetric large hazy white matter lesions 30 months after disease onset when steroids were discontinued. Patient 2: (G and H) Axial FLAIR sequences showing gyriform hyperintensities with edema similar to abnormalities previously reported in cases of anti-MOG-associated cortical encephalitis. ${ }^{6}$

medical legal consultation for Rogers Towers PA, Orlando Health, and Wilson, Elser, Moskowitz, Edelman \& Dicker LLP. T. Armangue received research support from the Mutua
Madrileña Foundation. Full disclosure form information provided by the authors is available with the full text of this article at Neurology.org/NN.

Figure 2 Brain biopsy of 2 patients with anti-MOG encephalitis initially misdiagnosed with small vessel CNS vasculitis
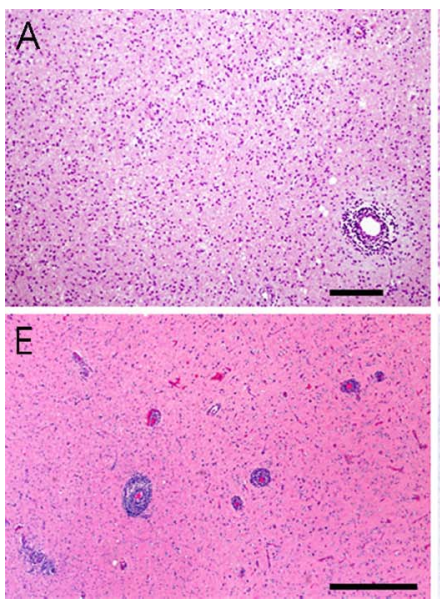
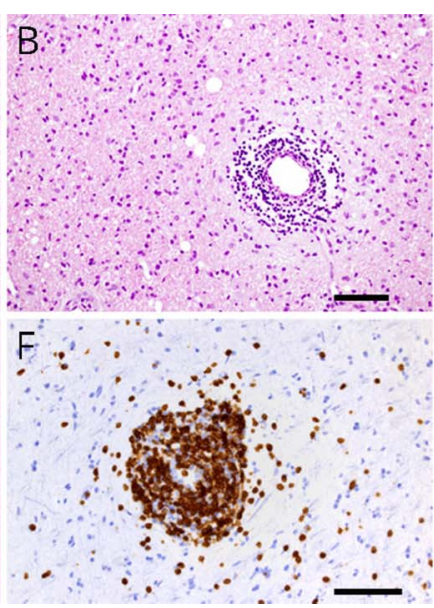

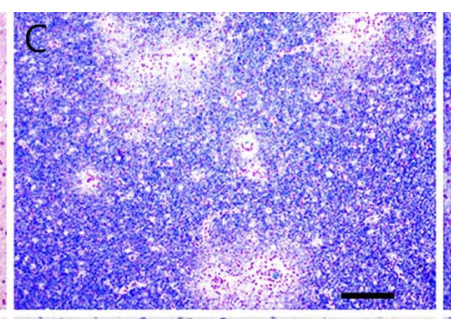

G
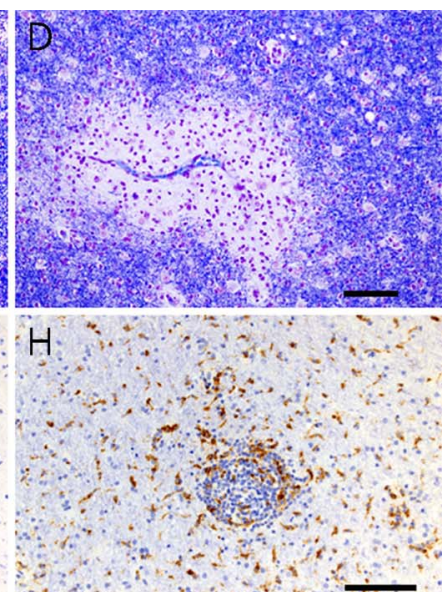

In patient 1, biopsy of the right temporal lobe showed small vessel perivascular lymphocytic infiltration (A, hematoxylin-eosin staining; $B$, magnification of the vessel shown in panel A). Inflammatory infiltrates included T and B lymphocytes (not shown) in association with edema, perivascular demyelination, and reactive gliosis ( $C$ and $D$, luxol fast blue staining). In patient 2 , biopsy of the left temporal lobe showed marked perivascular lymphocytic infiltrates involving the vessel wall (E, hematoxylin-eosin staining). The infiltrates were also composed of T lymphocytes ( $F$, CD3 immunostaining), B lymphocytes (G, CD20 immunostaining), and macrophages ( $\mathrm{H}$, anti-CD68 immunostaining). Myelin staining did not show clear evidence of demyelination (not shown). No necrosis or fibrin deposition was identified (not shown). Scale bar $200 \mu \mathrm{m}$ in A and C, $500 \mu \mathrm{m}$ in $\mathrm{E}$, and $100 \mu \mathrm{m}$ in $\mathrm{B}, \mathrm{D}$, and F-H. 


\section{Publication history}

Received by Neurology: Neuroimmunology \& Neuroinflammation August 16, 2018. Accepted in final form October 19, 2018.

\section{Appendix 1 Author contributions}

\begin{tabular}{|c|c|c|c|}
\hline Name & Location & Role & Contribution \\
\hline $\begin{array}{l}\text { Kristina } \\
\text { Patterson, } \\
\text { MD, PhD }\end{array}$ & $\begin{array}{l}\text { University of } \\
\text { Pennsylvania, } \\
\text { Philadelphia }\end{array}$ & Author & $\begin{array}{l}\text { Analyzed the data and } \\
\text { drafted the manuscript }\end{array}$ \\
\hline $\begin{array}{l}\text { Estibaliz } \\
\text { Iglesias, } \\
\text { MD, PhD }\end{array}$ & $\begin{array}{l}\text { University of } \\
\text { Barcelona, } \\
\text { Barcelona }\end{array}$ & Author & $\begin{array}{l}\text { Analyzed the data and } \\
\text { critically reviewed the } \\
\text { manuscript }\end{array}$ \\
\hline $\begin{array}{l}\text { Maclean } \\
\text { Nasrallah, } \\
\text { MD, PhD }\end{array}$ & $\begin{array}{l}\text { University of } \\
\text { Pennsylvania, } \\
\text { Philadelphia }\end{array}$ & Author & $\begin{array}{l}\text { Analyzed the data, critically } \\
\text { reviewed the manuscript, } \\
\text { and developed figure } 2\end{array}$ \\
\hline $\begin{array}{l}\text { Verónica } \\
\text { González- } \\
\text { Álvarez, MD }\end{array}$ & $\begin{array}{l}\text { University of } \\
\text { Barcelona, } \\
\text { Barcelona }\end{array}$ & Author & $\begin{array}{l}\text { Analyzed the data and } \\
\text { critically reviewed the } \\
\text { manuscript }\end{array}$ \\
\hline $\begin{array}{l}\text { Mariona } \\
\text { Suñol, MD }\end{array}$ & $\begin{array}{l}\text { University of } \\
\text { Barcelona, } \\
\text { Barcelona }\end{array}$ & Author & $\begin{array}{l}\text { Analyzed the data, critically } \\
\text { reviewed the manuscript, } \\
\text { and developed figure } 2\end{array}$ \\
\hline $\begin{array}{l}\text { Jordi Anton, } \\
\text { MD, PhD }\end{array}$ & $\begin{array}{l}\text { University of } \\
\text { Barcelona, } \\
\text { Barcelona }\end{array}$ & Author & $\begin{array}{l}\text { Analyzed the data and } \\
\text { critically reviewed the } \\
\text { manuscript }\end{array}$ \\
\hline $\begin{array}{l}\text { Albert Saiz, } \\
\text { MD, PhD }\end{array}$ & $\begin{array}{l}\text { University of } \\
\text { Barcelona, } \\
\text { Barcelona }\end{array}$ & Author & $\begin{array}{l}\text { Analyzed the data and } \\
\text { critically reviewed the } \\
\text { manuscript }\end{array}$ \\
\hline $\begin{array}{l}\text { Eric } \\
\text { Lancaster, } \\
\text { MD, PhD }\end{array}$ & $\begin{array}{l}\text { University of } \\
\text { Pennsylvania, } \\
\text { Philadelphia }\end{array}$ & Author & $\begin{array}{l}\text { Analyzed the data and } \\
\text { critically reviewed the } \\
\text { manuscript }\end{array}$ \\
\hline $\begin{array}{l}\text { Thaís } \\
\text { Armangue, } \\
\text { MD, PhD }\end{array}$ & $\begin{array}{l}\text { University of } \\
\text { Barcelona, } \\
\text { Barcelona }\end{array}$ & Author & $\begin{array}{l}\text { Designed and } \\
\text { conceptualized the study; } \\
\text { analyzed the data; drafted } \\
\text { the manuscript; and } \\
\text { developed the figures }\end{array}$ \\
\hline
\end{tabular}

\section{References}

1. Benseler SM, deVeber G, Hawkins C, et al. Angiography-negative primary central nervous system vasculitis in children: a newly recognized inflammatory central nervous system disease. Arthritis Rheum 2005;52:2159-2167.

2. Jarius S, Paul F, Aktas O, et al. MOG encephalomyelitis: international recommendations on diagnosis and antibody testing. J Neuroinflammation 2018;15: 134.

3. Höftberger R, Sepulveda M, Armangue T, et al. Antibodies to MOG and AQP4 in adults with neuromyelitis optica and suspected limited forms of the disease. Mult Scler 2015;21:866-874

4. Giannini C, Salvarani C, Hunder G, Brown RD. Primary central nervous system vasculitis: pathology and mechanisms. Acta Neuropathol 2012;123 759-772.

5. Benseler S, Pohl D. Childhood central nervous system vasculitis. Handb Clin Neurol 2013;112:1065-1078.

6. Ogawa R, Nakashima I, Takahashi T, et al. MOG antibody-positive, benign, unilateral, cerebral cortical encephalitis with epilepsy. Neurol Neuroimmunol Neuroinflamm 2017;4:e322. doi: 10.1212/NXI.0000000000000322. 


\title{
Neurology \\ Neuroimmunology \& Neuroinflammation
}

\author{
Anti-MOG encephalitis mimicking small vessel CNS vasculitis \\ Kristina Patterson, Estibaliz Iglesias, Maclean Nasrallah, et al. \\ Neurol Neuroimmunol Neuroinflamm 2019;6; \\ DOI 10.1212/NXI.0000000000000538
}

This information is current as of February 1, 2019

\section{Updated Information \& Services}

References

Citations

Subspecialty Collections

Permissions \& Licensing

Reprints including high resolution figures, can be found at:

http://nn.neurology.org/content/6/2/e538.full.html

This article cites 6 articles, 1 of which you can access for free at: http://nn.neurology.org/content/6/2/e538.full.html\#\#ref-list-1

This article has been cited by 5 HighWire-hosted articles: http://nn.neurology.org/content/6/2/e538.full.html\#\#otherarticles

This article, along with others on similar topics, appears in the following collection(s):

All Demyelinating disease (CNS)

http://nn.neurology.org//cgi/collection/all_demyelinating_disease_cns Autoimmune diseases

http://nn.neurology.org//cgi/collection/autoimmune_diseases Vasculitis

http://nn.neurology.org//cgi/collection/vasculitis

Information about reproducing this article in parts (figures,tables) or in its entirety can be found online at:

http://nn.neurology.org/misc/about.xhtml\#permissions

Information about ordering reprints can be found online:

http://nn.neurology.org/misc/addir.xhtml\#reprintsus

Neurol Neuroimmunol Neuroinflamm is an official journal of the American Academy of Neurology.

Published since April 2014, it is an open-access, online-only, continuous publication journal. Copyright

Copyright (C) 2019 The Author(s). Published by Wolters Kluwer Health, Inc. on behalf of the American

Academy of Neurology.. All rights reserved. Online ISSN: 2332-7812.

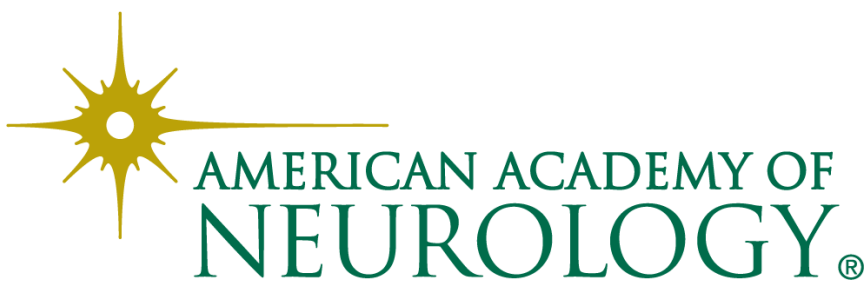

